\title{
Pemanfaatan Limbah Organik Untuk Kompos Pada Wilayah KPHP Unit XIII Kabupaten Muara Jambi
}

\author{
Rike Puspitasari Tamin, Fazriyas, Hamzah, Albayudi \\ Program Studi Kehutanan, Fakultas Kehutanan, Universitas Jambi, Indonesia \\ Email: rikepuspitasari_unja@yahoo.co.id
}

\begin{abstract}
ABSTRAK
Berdasarkan data Balai Pemantapan Kawasan Hutan Pangkal Pinang Tahun 2017 bahwa sebagian besar masyarakat yang bertempat tinggal di dalam kawasan KPHP Unit XIII adalah sebagai petani $(65,08 \%)$, dimana $83 \%$ masyarakat tersebut memiliki luas lahan di dalam kawasan hutan seluas 0-2 hektar dan 17\% sebesar 2,1-4 Ha. Lahan masyarakat tersebut sebagian besar ditanami kelapa sawit (41\%), cokelat (18\%), padi (11\%), dan sisanya merupakan jenis tanaman pertanian lainnya. Besarnya potensi limbah organik yang dihasilkan dari kegiatan bertani dan berkebun yang dilakukan oleh masyarakat maupun perusahaan (kelapa sawit dan HTI) merupakan satu hal yang dapat dimanfaatkan oleh petani/masyarakat untuk dijadikan pupuk hayati yaitu pupuk kompos. Kegiatan pengabdian kepada masyarakat yang dilakukan oleh Fakultas Kehutanan melibatkan mitra yaitu KPHP Unit XIII Kabupaten Muara Jambi yang berada di Desa Sungai Gelam. Tujuan dari kegiatan ini adalah untuk meningkatkan kemampuan mitra dalam pembuatan kompos sehingga bisa meningkatkan perekonomian masyarakat di sekitar kawasan hutan KPHP Unit XIII Muara Jambi. Tahapan kegiatan ini meliputi : pengurusan izin; kegiatan penyuluhan dengan materi berjudul "Pelatihan Pembuatan Kompos"; pembuatan demplot pembuatan kompos; dan evaluasi diakhir kegiatan. Hasil dari kegiatan ini yaitu mitra telah memiliki peningkatan ketrampilan dalam pembuatan kompos.
\end{abstract}

Kata Kunci: Kompos, KPHP Unit XIII Muara Jambi

\section{PENDAHULUAN}

Wilayah KPHP Unit XIII Kabupaten Muara Jambi secara administrasi berada pada Kecamatan Sungai Gelam, Kecamatan Kumpeh Ilir, dan Kecamatan Muara Sebo. Beradasarkan citra landsat Provinsi Jambi Tahun 2007, menunjukkan bahwa tutupan lahan pada areal KPHP Unit XIII merupakan areal perkebunan, pertanian lahan kering bercampur semak dan Hutan Tanaman Industri (HTI). Untuk areal perkebunan kelapa sawit sendiri didominasi oleh lahan perkebunan milik swasta/perusahaan dan terdapat juga kebun kelapa sawit milik masyarakat.

Berdasarkan data Balai Pemantapan Kawasan Hutan Pangkal Pinang (2017) menunjukkan bahwa sebagian besar masyarakat yang bertempat tinggal di dalam kawasan KPHP Unit XIII adalah sebagai petani $(65,08 \%)$, dimana $83 \%$ masyarakat tersebut memiliki luas lahan di dalam kawasan hutan seluas 0-2 hektar dan 17\% sebesar 2,1-4 Ha. Lahan masyarakat tersebut sebagian besar ditanami kelapa sawit (41\%), cokelat (18\%), padi (11\%), dan sisanya merupakan jenis tanaman pertanian lainnya (padi, jagung, cabai, timun, kacang, pisang, duku, durian, karet, pinang, dan lainnya).

Besarnya potensi limbah organik yang dihasilkan dari kegiatan bertani dan berkebun yang dilakukan oleh masyarakat maupun perusahaan (kelapa sawit dan HTI) merupakan satu hal yang dapat dimanfaatkan oleh petani/masyarakat untuk dijadikan pupuk hayati yaitu pupuk 
kompos. Limbah organik dapat diperoleh dari kegiatan bertani itu sendiri yang dilakukan oleh petani/masyarakat dan limbah organik yang dihasilkan dari perkebunan swasta serta HTI yang berada dalam kawasan KPHP. Pupuk kompos dapat dijadikan sebagai pupuk organik yang dapat dimanfaatkan kembali oleh petani didalam kegiatan bercocok tanam mereka.

Selain dapat membantu petani didalam kegiatan bercocok tanam mereka, pemanfaatan limbah organik untuk diolah menjadi kompos diharapkan dapat meningkatkan perekonomian petani dan masyarakat dalam kawasan dimana kompos tersebut dapat dijual kepada perkebunan kelapa sawit milik swasta/perusahaan dan HTI yang berada dalam kawasan KPHP Unit XIII.

\title{
Permasalahan Mitra
}

Berdasarkan uraian analisis situasi di atas diperoleh gambaran mengenai kondisi mitra dalam hal ini masyarakat yang bertempat tinggal di sekitar dan di dalam kawasan KPHP Unit XIII Kabupaten Muara Jambi yang akan dijadikan mitra dalam kegiatan pengabdian kepada masyarakat ini. Kondisi wilayah yang didominasi oleh perkebunan kelapa sawit (perusahaan dan lahan masyarakat), HTI, dan usaha pertanian lainnya memiliki potensi penghasil limbah organik yang tidak termanfaatkan. Masyarakat/petani belum dapat memanfaatkan limbah organik tersebut menjadi sesuatu yang bisa digunakan kembali untuk dijadikan pupuk kompos yang dapat digunakan dalam kegiatan bertani/bercocok tanam mereka dan secara ekonomi dapat meningkatkan tingkat perekonomian mitra. Untuk itu perlu adanya transfer ilmu pengetahuan dan teknologi dari tim kepada mitra agar mitra dapat mandiri kedepannya dalam membuat kompos yang dapat digunakan dalam usaha bertani mitra.

\section{SOLUSI YANG DITAWARKAN}

Berdasarkan permasalahan mitra yang telah diuraikan di atas, tim pengabdian kepada masyarakat memberikan beberapa solusi terkait yang dapat menyelesaikan permasalahn tersebut, antara lain :

1. Memberikan penyuluhan kepada mitra tentang teknik pembuatan kompos dengan memanfaatkan limbah yang tesedia.

2. Memberikan demonstrasi dan pelatihan kepada mitra sehingga dapat meingkatkan kemampuan mitra dalam pembuatan kompos.

Dari beberapa solusi yang ditawarkan kepada mitra, tim pengabdian kepada masyarakat Fakultas kehutanan memiliki harapan besar bahwa mitra dapat lebih terampil dan menguasai cara dan teknik pembuatan kompos.

\section{METODE PELAKSANAAN}

\section{Tempat dan Waktu}

Kegiatan pengabdian kepada masyarakat ini dilaksanakan di kawasan hutan KPHP Unit XIII Muara Jambi khususnya di Desa Sungai Gelam. Waktu kegiatan bulan Juni -Oktober 2020.

\begin{abstract}
Alat dan Bahan
Alat yang digunakan antara lain : cangkul, sekop, gerobak sorong, parang, sendok semen, selang air, pipa ukuran $1 / 2$ ", thermometer, infokus, kamera. Sedangkan bahan yang digunakan antara lain : bahan untuk membuat bak kompos (batu bata, semen, pasir, plastik cor hitam, papan); bahan baku untuk pembuatan kompos (tandan sawit kosong, ranting dan seresah sisa kegiatan bertani; ranting dan seresah perkarangan dan sampah rumah tangga); bahan decomposer carrier (EM4, kotoran kambing, kotoran sapi, dedak).
\end{abstract}

\section{Prosedur Kegiatan}


Prosedur kegiatan pengabdian ini terdiri dari beberapa tahapan kegiatan, antara lain :

Pengurusan Izin

Pengurusan izin dilakukan ke Kepala KPHP Unit XIII Muara Jambi dan Pengurus Koperasi Multi Usaha Mandiri.

\section{Penyuluhan}

Kegiatan penyuluhan ini bertujuan untuk meningkatkan pengetahuan dan keterampilan mitra dalam pembuatan kompos. Kegiatan penyuluhan dalam hal ini membawa narasumber yang ahli dibidangnya yang Bapak Ir. Richard Robintang Parulian Napitupulu, S.Hut., M.Sc dengan judul penyuluhan "Pelatihan Peningkatan Kemampuan Mitra Dalam Pembuatan Kompos".

\section{Demontrasi dan Pelatihan}

Setelah kegiatan penyuluhan dilakukan, kegiatan selanjutnya adalah demonstrasi dan pelatihan. Dalam kegiatan demonstrasi dan pelatihan ini, tim pengabdian kepada masyarakat telah membangun bak kompos untuk mempermudah mitra di dalam pembuatan kompos

\section{Evaluasi Kegiatan}

Evaluasi kegiatan dilakukan diakhir kegiatan untuk melihat keberhasilan mitra dalam membuat kompos.

\section{HASIL DAN LUARAN YANG DICAPAI}

Kegiatan pengabdian kepada masyarakat ini terbagi dalam beberapa kegiatan, antara lain : pengurusan izin dan pengaturan waktu pelaksanaan kegiatan yang dilakukan di kantor wilayah KPHP Unit XIII Muara Jambi dan di koperasi Multi Usaha Mandiri, kegiatan penyuluhan , praktek demplot pembuatan kompos, serta evaluasi akhir kegiatan.

\section{Kegiatan Pengurusan Izin}

Kegiatan pengurusan izin pertama kali dilakukan di kampus program studi kehutanan Universitas Jambi dan di Kantor Koperasi Multi Usaha Mandiri.
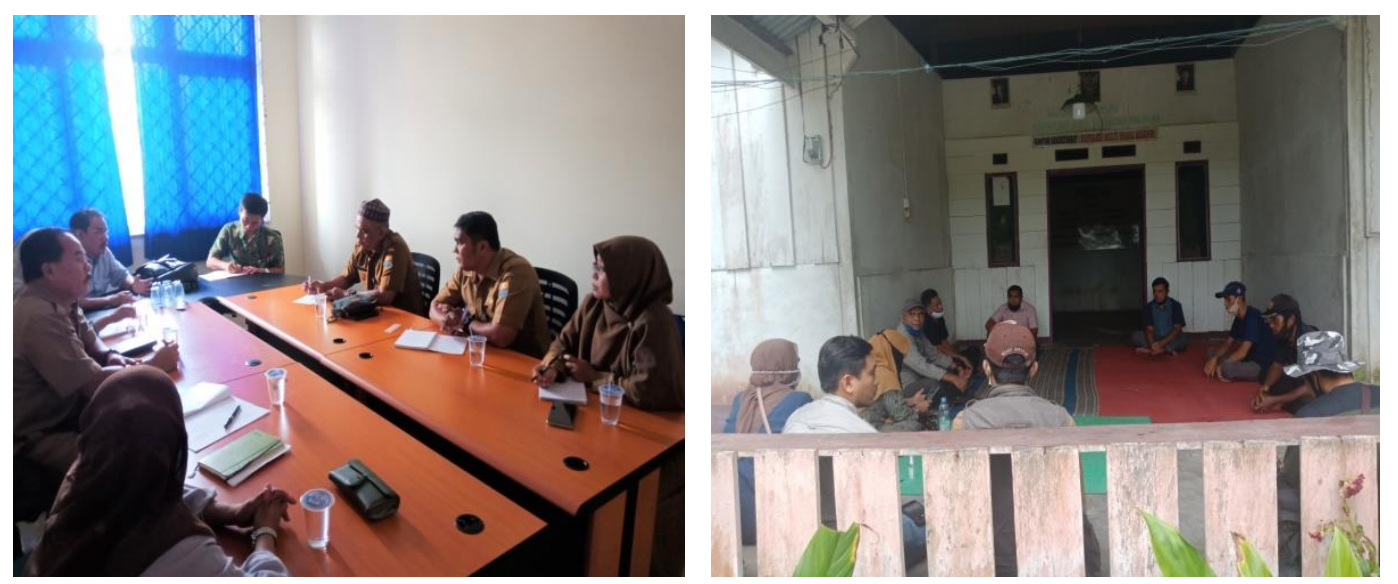

Gambar 1. Pengurusan Izin dan Koordinasi Kegiatan Pengabdian Kepada Masyarakat di

Kampus Mendalo dan Koperasi Multi Usaha Mandiri yang berlokasi di Desa Sungai Gelam

\section{Kegiatan Penyuluhan/Materi Pembuatan Kompos}

Sebelum kegiatan penyuluhan dilakukan, pertama kali diisi dengan sambutan serta arahan dari Kepala KPHP Unit XIII Muara Jambi Bapak Asrizal, S.P., M.Si, kata sambutan dan arahan dari Ketua Koperasi Multi Usaha Mandiri Bapak Ansori dan sambutan dari Tim Pengabdian yang dalam hal ini diwakili oleh Ir. Fazriyas, M.Si., I.PU. 

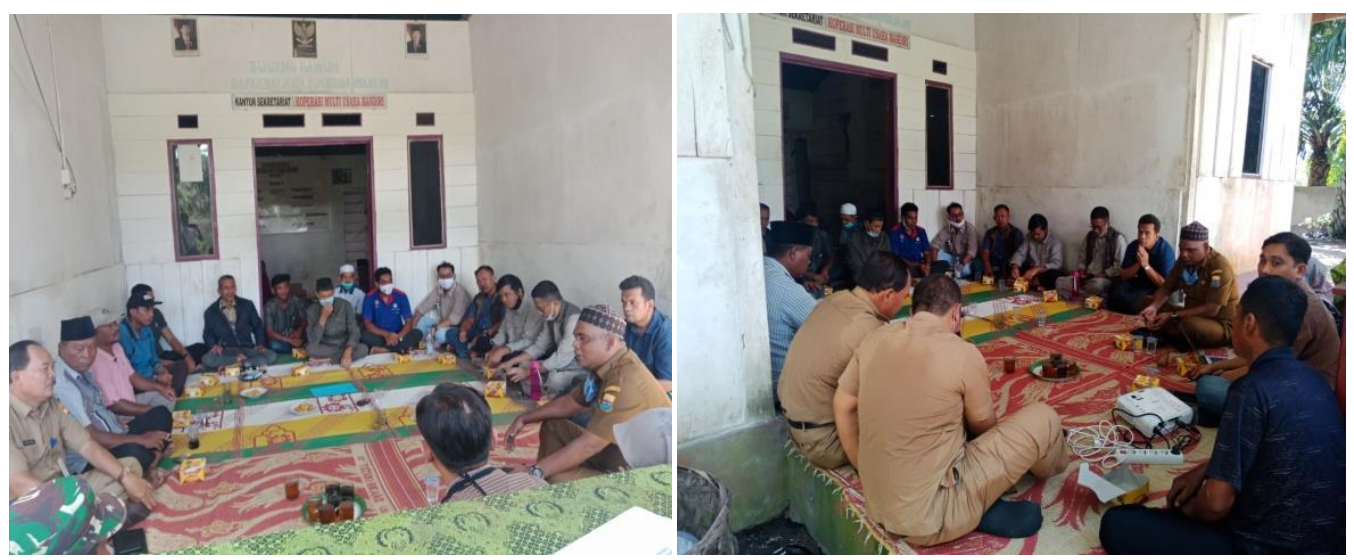

Gambar 2. Kata Sambutan Dari Kepala KPHP Unit XIII Muara Jambi, Ketua Koperasi Multi Usaha Mandiri dan Perwakilan Tim Pengabdian Kepada Masyarakat Program Studi

Kehutanan

Kegiatan penyuluhan ini diikuti oleh beberapa staf KPHP Unit XIII Muara Jambi, Penyuluh Kehutanan, Ketua Koperasi Multi Usaha Mandiri berserta anggotanya, dan masyarakat yang berada di sekitar kawasan hutan. Penyuluhan tentang pembuatan komposi ini dilberikan oleh narasumber dari Dosen Program Studi Kehutanan Bapak Ir. Richard Robintang Parulian Napitupulu, S.Hut., M.Sc dengan judul materi "Pelatihan Pembuatan Kompos".
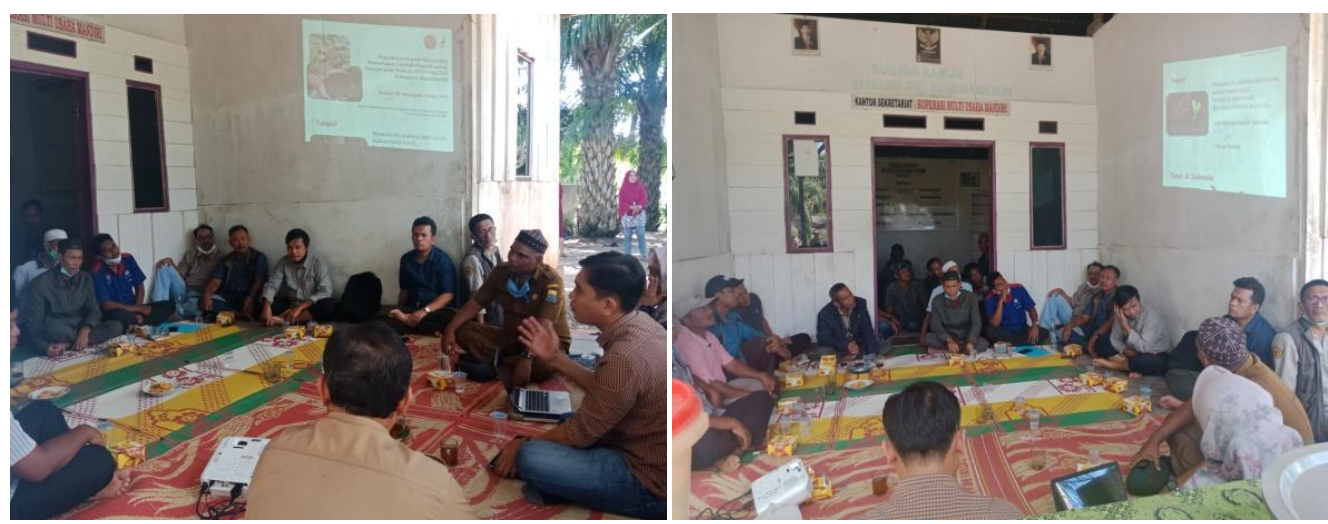

Gambar 3. Kegiatan Penyuluhan Pembuatan Kompos

Materi penyuluhan yang diberikan oleh tim ahli terkait pembuatan kompos terdiri dari : limbah apa saja yang tersedia di sekitar kawasan KPHP Unit XIII Muara Jambi Resort Sungai Gelam yang potensial dapat dijadikan bahan baku utama didalam pembuatan kompos, bahan baku tambahan yang digunakan dalam pembuatan kompos, pembangunan bak kompos, dan bagaimana menghasilkan kompos dengan kualitas terbaik

\section{Kegiatan Demplot Pembuatan Kompos}

Sebelum melakukan praktek pembuatan kompos di demplot yang telah ditentukan, tim pengabdian bekerjasama dengan mitra telah melakukan pembuatan 2 bak kompos dalam hal ini pembuatan kompos dilakukan oleh anggota dari koperasi Multi Usaha Mandiri. 


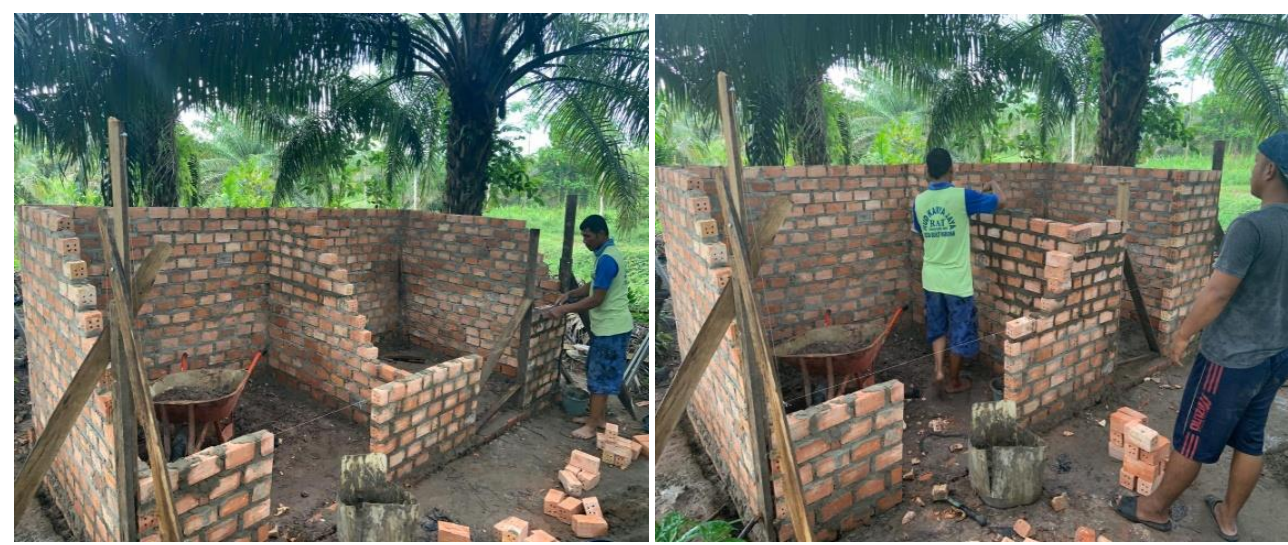

Gambar 4. Proses Pembuatan Bak Kompos

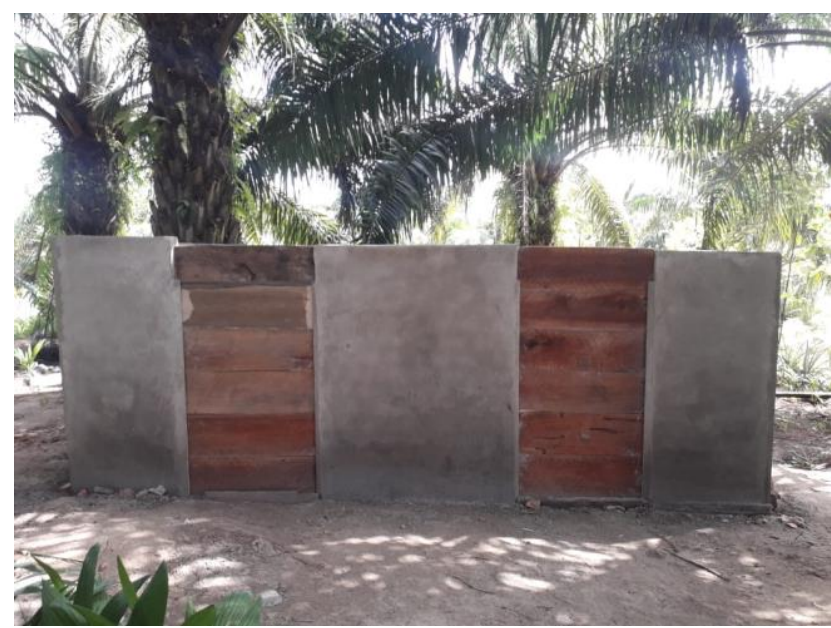

Gambar 5. Bak Kompos Yang Siap Digunakan
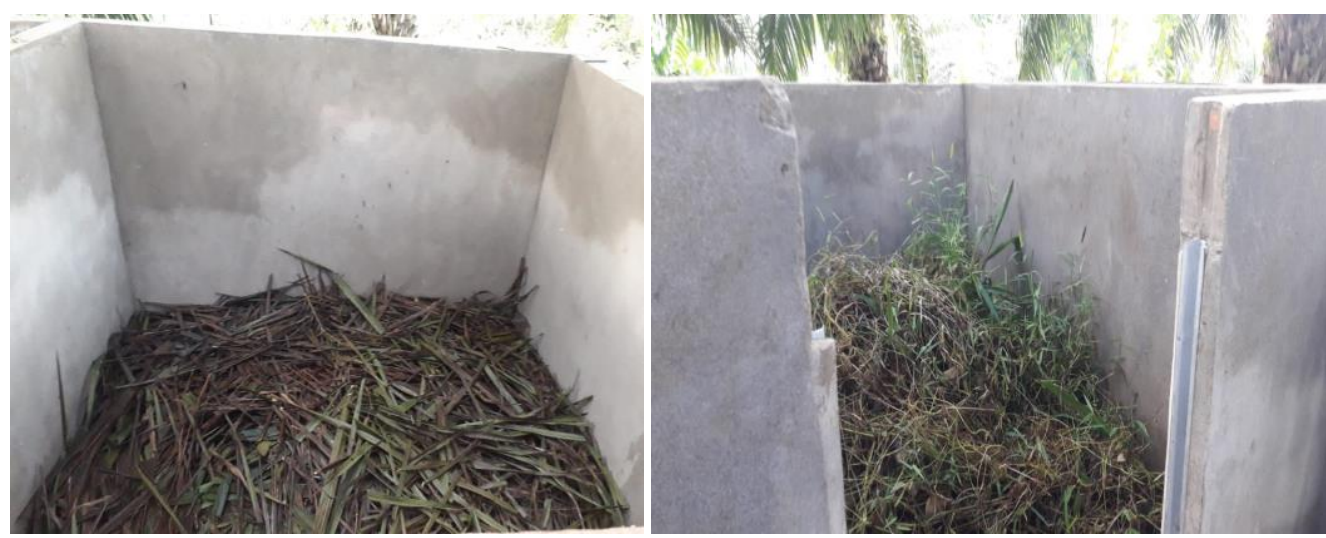

Gambar 6. Salah Satu Bahan Pembuatan Kompos 

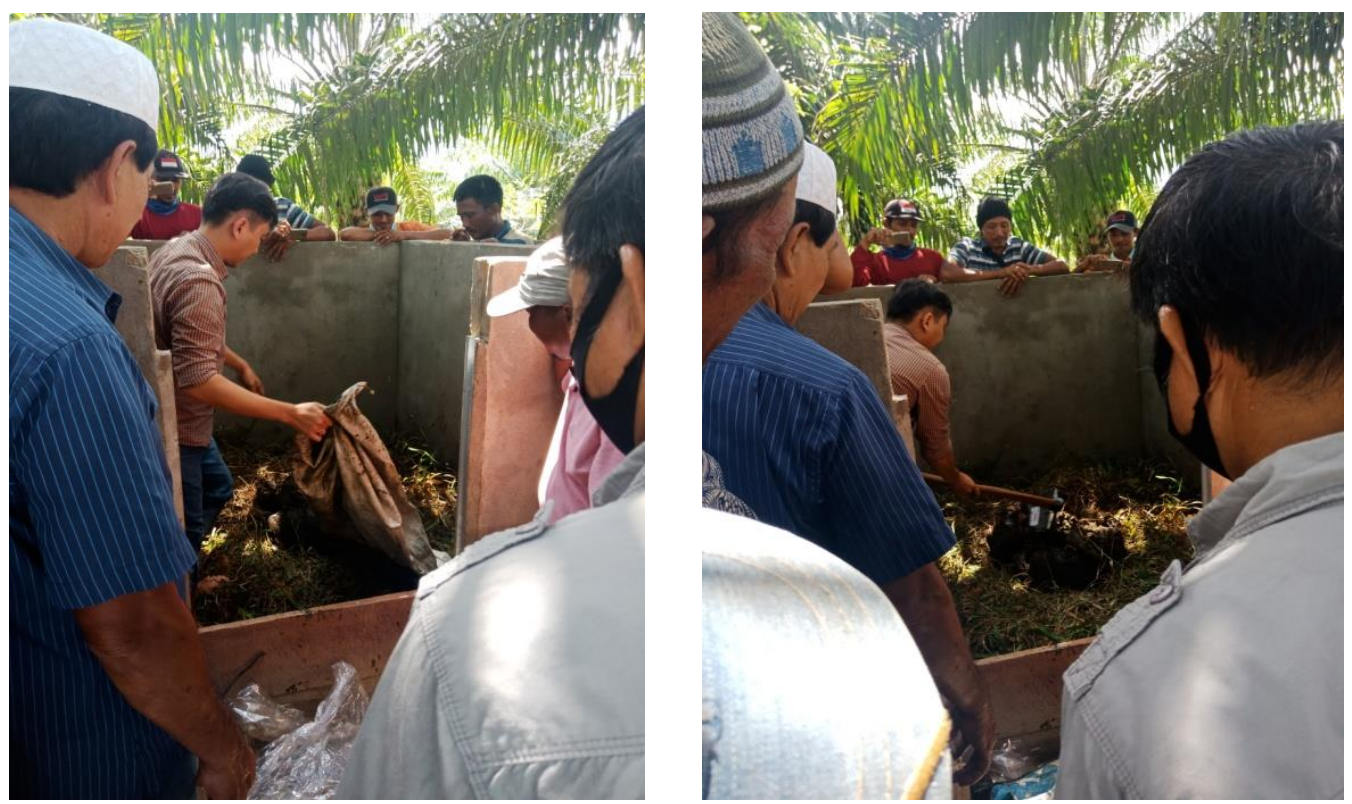

Gambar 7. Praktek/Demonstrasi Pembuatan Kompos

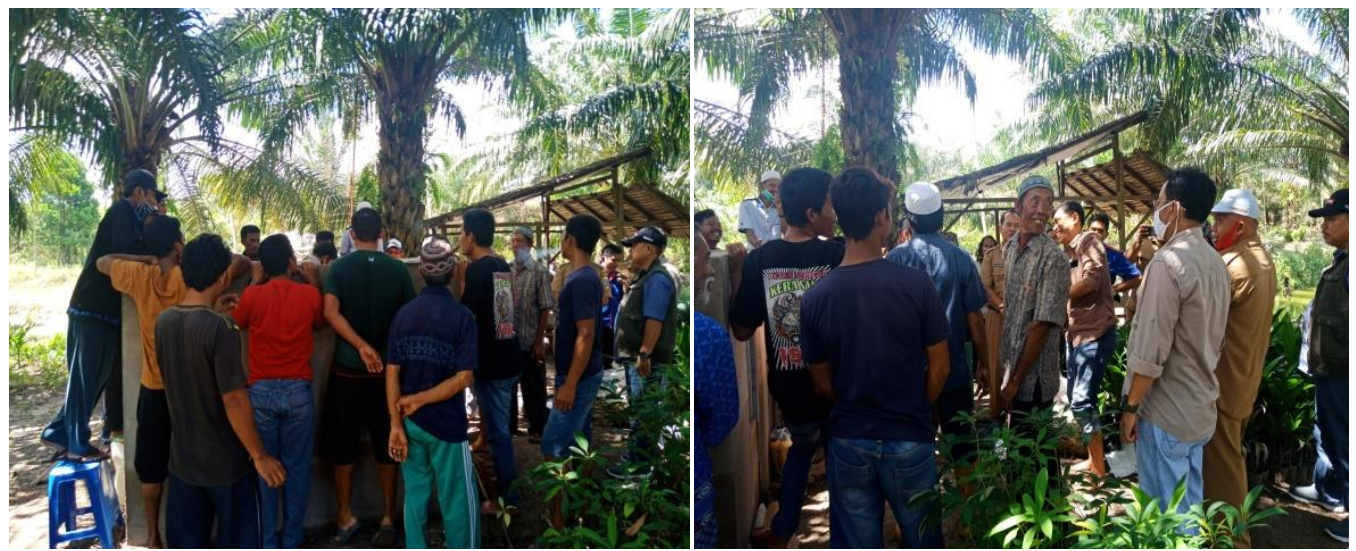

Gambar 8. Peserta Pelatihan Yang Antusias Memperhatikan Praktek Pembuatan Kompos

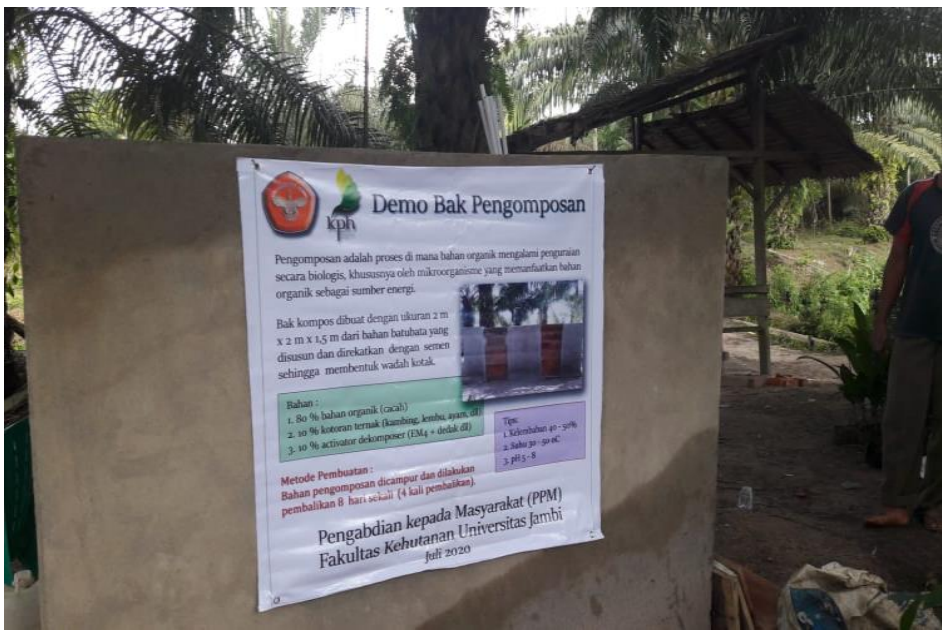

Gambar 9. Demo Bak Pengomposan 


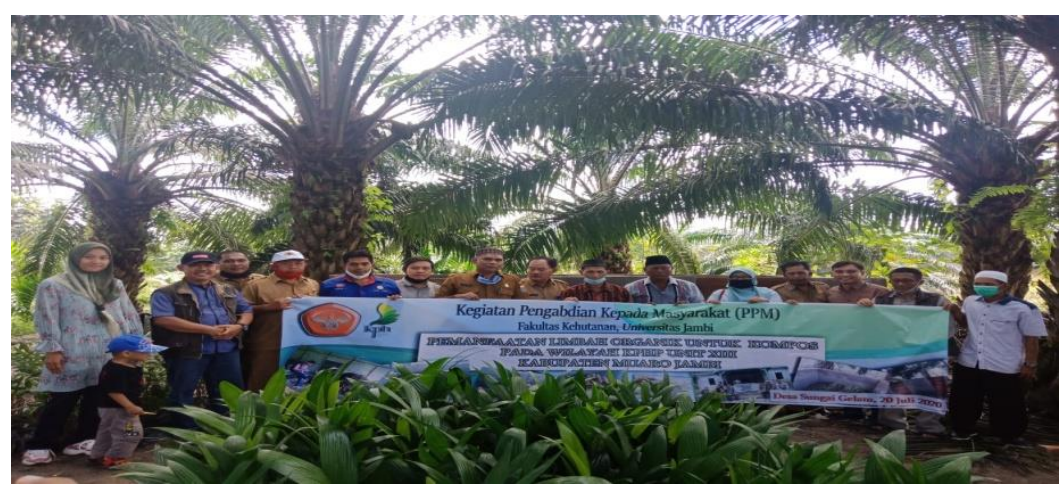

Gambar 10. Foto Bersama di Akhir Kegiatan

\section{Evaluasi Akhir}

Evaluasi akhir bertujuan untuk mengetahui berapa besar tingkat kerberhasilan didalam membuat kompos oleh masyarakat dan anggota koperasi multi usaha mandiri yang telah diberikan pelatihan pembuatan kompos.

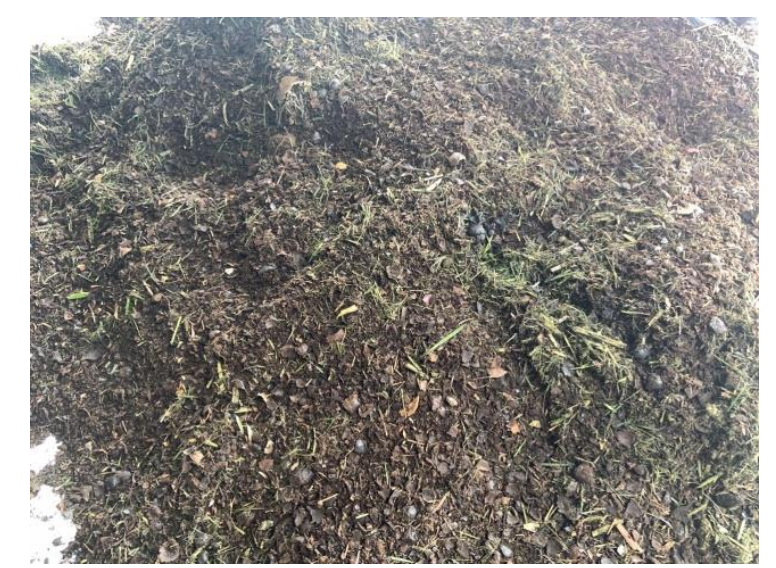

Gambar 11. Kompos Setengah Jadi

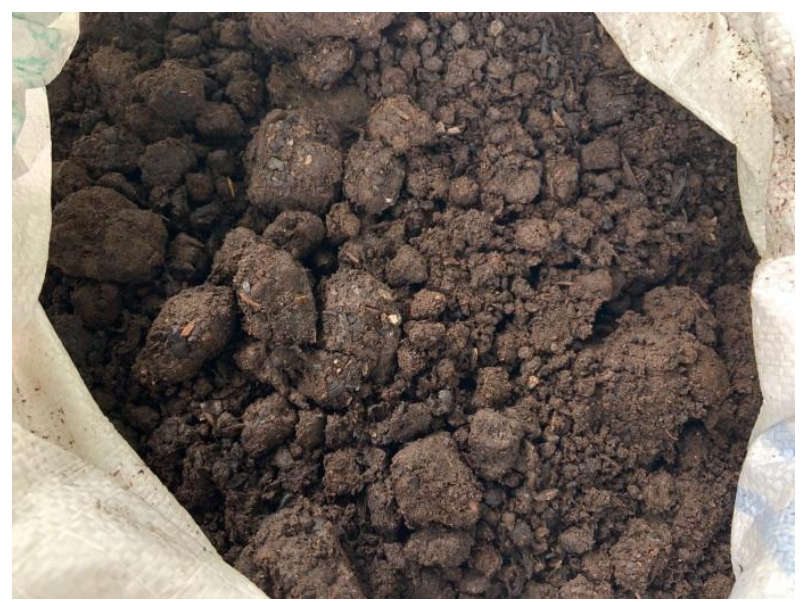

Gambar 12. Kompos Yang Menggumpal 


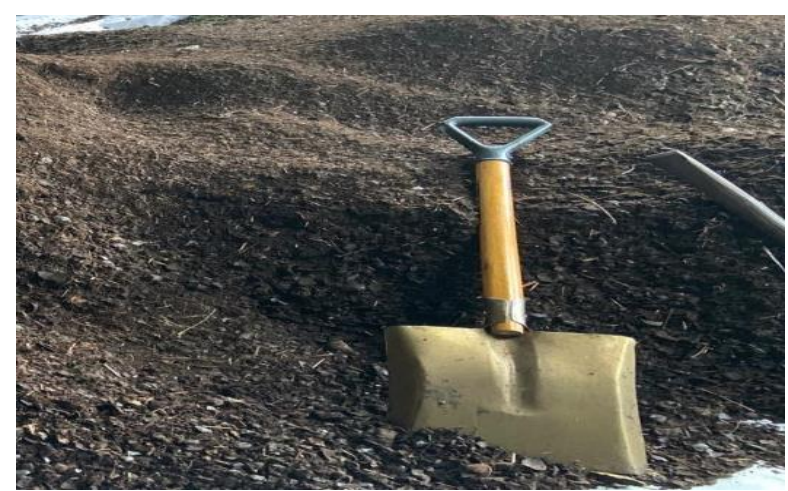

Gambar 13. Kompos Yang Sudah Jadi

KESIMPULAN DAN SARAN

\section{Kesimpulan}

Kesimpulan dari kegiatan pengabdian kepada masyarakat adalah mitra telah memiliki peningkatan kemampuan dalam pembuatan kompos.

\section{Saran}

Saran dari kegiatan pengabdian kepada masyarakat ini yaitu perlu penambahan bak kompos sehingga dapat menghasilkan kuantititas kompos yang cukup besar dan pembelian mesin pencacah untuk mencacah bahan kompos sehingga proses pembuatan kompos menjadi lebih singkat.

\section{UCAPAN TERIMA KASIH}

1. DIPA-PNBP Fakultas Kehutanan Skema Pengabdian Kepada Masyarakat Universitas Jambi Nomor : 023.17.2.677565/2020 Tanggal 27 Desember 2019, dan Surat Perjanjian Pelaksanaan Pengabdian Kepada Masyarakat Nomor : 1446/UN21.18/AM.SPK/2020, Tanggal 20 April 2020.

2. Kepala dan Staf KPHP Unit XIII Kabupaten Muara Jambi.

3. Ketua dan Anggota Koperasi Multi Usaha Mandiri

\section{DAFTAR PUSTAKA}

Balai Pemantapan Kawasan Hutan. 2017. Rencana Pengelolaan Hutan Jangka Panjang (RPHJP) Kesatuan pengelolaan Hutan (KPHP) Muara Jambi Unit XIII. Balai Pemantapan Kawasan Hutan. Pangkal Pinang.

Fazriyas. 2017. Rencana Pengelolaan Hutan Jangka Panjang (RPHJP) Kesatuan pengelolaan Hutan (KPHP) Muara Jambi Unit XIII. Balai Pemantapan Kawasan Hutan. Pangkal Pinang. 